\title{
Hantaan Virus: Genetic Diversity, Diseases, Hosts, Symptoms, Diagnosis
}

\section{Parul Gupta*}

Student at CT University, Ludhiana, India

*Corresponding Author: Parul Gupta, Student at CT University, Ludhiana, India.
Received: April 18, 2020

Published: May 12, 2020

(C) All rights are reserved by Parul Gupta.
Hantaviruses is a member of bunyavirus family of viruses. This bunyavirus is a huge family having 5 genera: bunyavirus, phlebovirus, nairovirus, tospovirus and hantavirus, consisting of about 300 viruses that infect plants, animal and humans as well [3]. The virus was named after of the river Hantan. The causative agent of Korean Hemerologic fever was extracted from rodent 'Apodemus agrarius' found near Hantan river in South Korea [5]. They are characterized by grid-like pattern of the outer surface which shows projections of glycoprotein of $12 \mathrm{~nm}$ from lipid bilayer (Figure 1). They are enveloped, single-stranded, negative-sense RNA viruses.

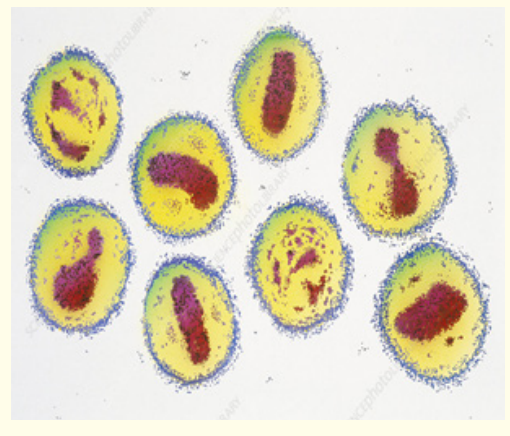

Figure 1: Hantavirus.

These projections are composed of heterodimers of Gn and Gc Polysaccharides which attack the endothelial, epithelial, macrophage, follicular dendritic, and lymphocyte cells through the fitting of the viral glycoprotein to the host's cell surface receptor [4].

\section{Genetic diversity of hantavirus}

Hantavirus consists of a negative-sense RNA genetic material which contain three segments: L (large), M (medium), and S (small) segments (Figure 2). These segments encodes different factors [3]:

- $\quad$ S segment encodes nucleocapsid protein (NP)

- $\quad$ M segment encodes enveloped glycoproteins (Gn nad Gc)

- L segment encodes RNA polymerase.

Diseases caused by Hantavirus

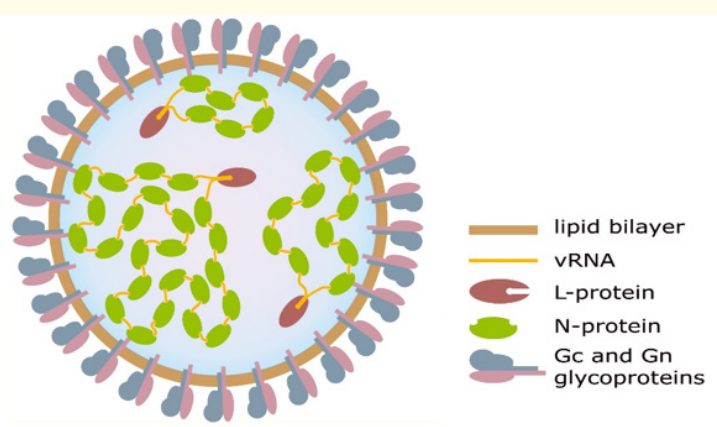

Figure 2: Genetic diversity of Hantavirus.

On the basis of the geographical distribution of the rodent reservoir and the type of disease they cause, the hantavirus are called as Old World and New World:

- $\quad$ Old World Hantavirus causes haemorrhagic fever with renal syndrome (HFRS).

- New World Hantavirus causes Hantavirus pulmonary syndrome (HPS) [1].

Haemorrhagic fever with renal syndrome (HFRS)- HFRS is a disease that affects the kidney nd is characterized by the haemorrhagic manifestations and improper function of the kidney. The incubation period for HFRS is about 10-6 weeks. The HFRS may either transfer between rodents or through their remains, may also transfer to human (Figure 3). The causative agent of HFRS are Hantaan virus (HTNV), Amur virus (AMV), Dobrava virus(DOBV), Seoul virus(SEOV), Puumala virus(PUUV).

- Hantaan virus, Amur virus and Dobrava virus causes severe disease.

- $\quad$ Seoul virus causes moderate disease.

- Puumala virus cause mild disease.

The viruses which causes the HFRS have different primary hosts as shown in table 1 [3].

These viruses are distributed in different locations. 


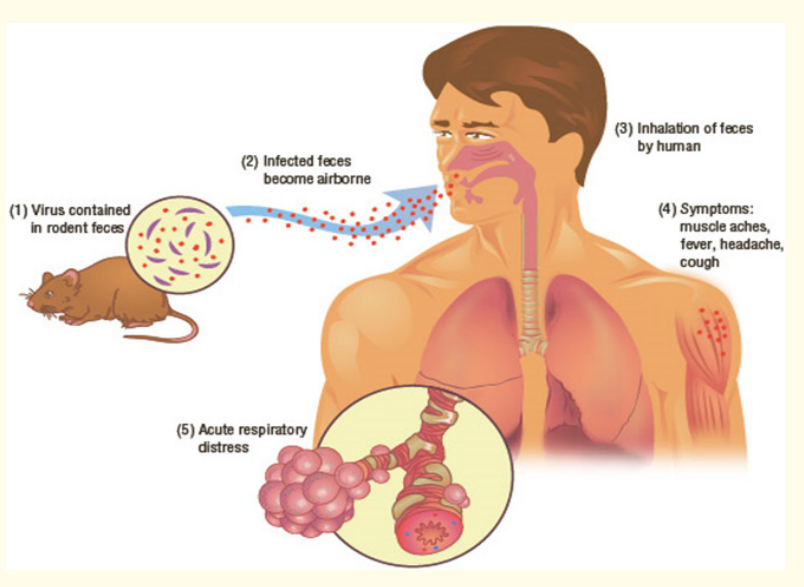

Figure 3: Transmission for haemorrhagic fever with renal syndrome.

\begin{tabular}{|l|l|l|}
\hline S. No & \multicolumn{1}{|c|}{ Viruses } & \multicolumn{1}{|c|}{ Hosts } \\
\hline 1. & Hantaan virus & $\begin{array}{l}\text { Apodemus agrarius (the striped field } \\
\text { mouse) }\end{array}$ \\
\hline 2. & Seoul virus & $\begin{array}{l}\text { Rattus norvegicus (the Norway rat) } \\
\text { Rattus rattus (the black rat) }\end{array}$ \\
\hline 3. & Puumala virus & $\begin{array}{l}\text { Clethrionomys glareolus (the bank } \\
\text { vole) }\end{array}$ \\
\hline 4. & Dobrava virus & $\begin{array}{l}\text { Apodemus flavicollis (the yellow- } \\
\text { necked field mouse) }\end{array}$ \\
\hline
\end{tabular}

Table

Hantaan virus is found in Asia, Far East Russia. Dobrava virus is found in Europe Balkans. Puumala virus is found in Europe. Only Seoul virus is Worldwide. There are five phases of HFRS: Febrile, Hypotensive, Oliguric, Polyguric and Convalescent. These five phases are distinguish on the basis of symptoms. The first phase, Febrile is characterized by thirst, restlessness, nausea, and vomiting. In Hypotensive phase, the patients suffers from shock and mental confusion. In this stage, vascular leakage, abdominal pain, and tachycardia are observed. After this stage, patients are at great risk for hypertension, pulmonary edema, and complications in kidney. Death may also occur in the complication situation [4].

Hantavirus pulmonary syndrome (HPS): HPS is a respiratory disease which is transmitted either by direct contact with rodents or from person to person through close contact in which one is already a victim of the disease (Figure 4). The virus transfer through hosts include- deer mouse, white-tailed mouse, cotton rat and rice rat. The incubation period for HPS is 9 - 33 days. The There are two phases of HPS. The first phase shows symptoms like flu, fever, chills, headaches, muscle aches, vomiting, diarrhea or abdominal

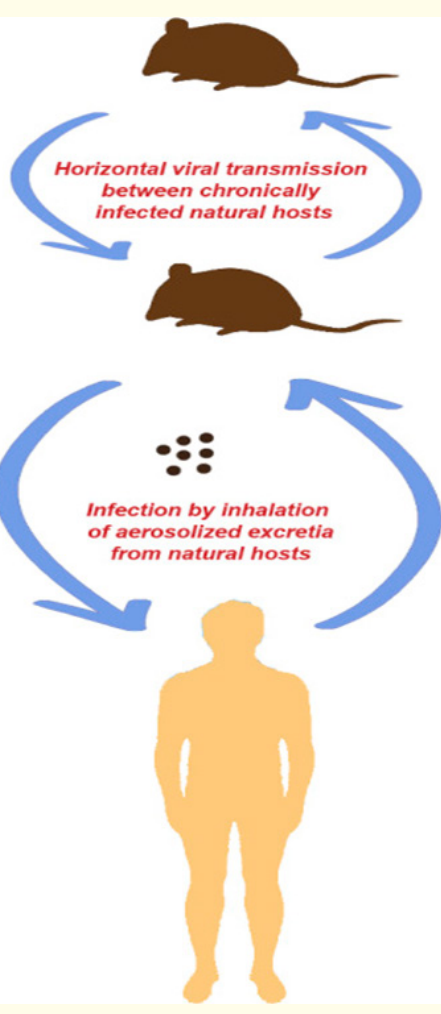

Figure 4: Transmission for haemorrhagic pulmonary syndrome.

pain. The second phase shows symptoms like a cough with secretions, breathing problem, accumulation of fluid in the lungs, low blood pressure and cardiovascular disease [2,6].

\section{Diagnosis}

The diagnosis of HFRS and HPS can be done in two ways [4]:

1. Molecular diagnostics: This is a rapid and the most sensitive method for the detection of viral genome. The hantavirus genome can be rapidly detected by reverse transcription-PCR (RT-PCR) using blood sample or serum sample.

2. Serological tests: As there is a presence of $\operatorname{IgM}$ and $\operatorname{IgG}$ antibodies with $\mathrm{N}$ protein. These antibodies can be detect by serological test using serum sample.

\section{Conclusion}

As there is no availability of the vaccine, antiviral or any immunotherapeutics for HFRS and HPS. But through the early detection of the virus may help to control the conditions. The prognosis of the virus may influence the disease to enter into mild phase. 


\section{Bibliography}

1. Zupanc TA., et al. "Hantavirus infections". Clinical Microbiology and Infection 21 (2019): e6-e16.

2. Centers for disease control and prevention. "Virology".

3. Jonsson CB., et al. "A global perspective on hantavirus ecology, epidemiology, and disease". Clinical Microbiology Reviews 23.2 (2010): 412-441.

4. Mir MA. "Hantaviruses". Clinics in Laboratory Medicine 30.1 (2010): 67-91.

5. Razzauti Maria. "Microevolution of Puumala hantavirus in its host, the bank vole (Myodes glareolus)" (2012).

6. Mayo clinic. "Hantavirus pulmonary syndrome".

\section{Assets from publication with us}

- Prompt Acknowledgement after receiving the article

- Thorough Double blinded peer review

- Rapid Publication

- Issue of Publication Certificate

- High visibility of your Published work

Website: https://www.actascientific.com/

Submit Article: https://www.actascientific.com/submission.php Email us: editor@actascientific.com

Contact us: +919182824667 